\title{
Wu Hung, Making History: Wu Hung on Contemporary Art andWu Hung on Contemporary Chinese Artists
}

\section{Emmanuel Lincot}

\section{(Q) OpenEdition}

Journals

Édition électronique

URL : http://journals.openedition.org/chinaperspectives/5324

DOI : 10.4000/chinaperspectives.5324

ISSN : 1996-4617

Éditeur

Centre d'étude français sur la Chine contemporaine

Édition imprimée

Date de publication : 15 septembre 2010

ISSN : 2070-3449

\section{Référence électronique}

Emmanuel Lincot, «Wu Hung, Making History: Wu Hung on Contemporary Art andWu Hung on

Contemporary Chinese Artists », China Perspectives [En ligne], 2010/3 | 2010, mis en ligne le 09 février 2011, consulté le 24 septembre 2020. URL : http://journals.openedition.org/chinaperspectives/5324 ; DOI : https://doi.org/10.4000/chinaperspectives.5324

Ce document a été généré automatiquement le 24 septembre 2020

(c) All rights reserved 


\title{
Wu Hung, Making History: Wu Hung on Contemporary Art andWu Hung on Contemporary Chinese Artists
}

\author{
Emmanuel Lincot
}

1 Wu Hung, Making History: Wu Hung on Contemporary Art, Hong Kong, Time Zone 8, 2008.

2 Wu Hung on Contemporary Chinese Artists, Hong Kong, Time Zone 8, 2009.

University of Chicago art history professor Wu Hung has written two important works published by Time Zone 8 , a publisher specialising in Chinese contemporary art under the direction of Beijing-based Robert Bernell. Making History is reminiscent of L'écriture de l'histoire (The Writing of History)by Michel de Certeau, but focuses on an entirely different aspect - that of China and its artists. Adorned by a cover featuring a work by Xu Bing, Making History takes stock of the complexity facing researchers in combining the theory of art of the most diverse origins (European, American, Japanese, Chinese) with sensitive experiences fed by political reflections which, over the course of three decades, have given rise to a rich and profound renewal of not only Marxist and Kantian but also Confucian studies.

The issue of the ethical limits of art and aesthetics occupies an essential place in the ideological and social criticism undertaken by Li Zehou in China and Kojin Karatani in Japan. Wu Hung highlights these authors' important contribution in opening up a very large perspective to aesthetics as a condition for the renaissance of subjectivity and moral obligation. This historiographic precondition is all the more gratifying in that it helps better understand the exchanges between writings (still little known in Europe, although they reinterpret notions strongly imbued with ideology and cultural values: modernity and post-modernity) and works of Chinese artists, who have since the 1990s aroused keen interest among Western galleries. Wu Hung describes the main currents of this contemporary art, painting especially, which it would be wrong to dismiss as pastiches of Western art inasmuch as they incorporate strong references to the Cultural Revolution and make for a veritable "style"(p. 8). This contributes not only 
to the atomisation of practices of art in China but also to its own "deterritorialisation" (p. 32) by integrating international exhibitions that contribute to its renown. There is a reference to the Venice as well as to the Shanghai Biennale, which in 2000 earned notoriety thanks to a counter-exhibition organised by the radical artist Ai Weiwei and critic and curator Feng Boyi.

The interest that Wu Hung brings to bear on places invested with memories such as Tiananmen or Beijing's Dashanzi area, which now hosts artists' studios and galleries, gives rise to a dual and contradictory reflection on urban heritage renewal as well as on the taste for ruins. The first points to a posture (that of artists) and a choice (that of the municipality) that are not necessarily in agreement even though both are acting in a context in which the contemporary challenges modernity over its distinctive signs and its main characteristic (in Europe at least): precisely the cults of ruins. Defining this period (of modernity), historians Lü Peng and Yi Dan trace a continuum between the May Fourth Movement of 1919 and the 1980s, bypassing the Mao era, which figures parenthetically. This historiographic debate goes far beyond issues inherent in Chinese culture seen in isolation. In a concluding declaration, Wu Hung writes: "Contemporary Asian art is no longer confined to a single geographical sphere, nor is it defined by the artist's ethnicity"(p. 251). This redefinition of the global geography of arts has propelled major Chinese artists onto the international scene: Zhang Dali, Liu Xiaodong, Lin Yilin, Rong Rong, and Ma Liuming, as well as Wang Guangyi, Wang Gongxin, Cai Guoqiang, and Hong Hao.

Wa Hung notes that in varying degrees these artists have developed their quests around three major themes: memory/history, nature/culture, and local/global. They have either chosen a biographic discourse or adopted a performative and "experimental" mode (shiyan meishu) at the borders of contemporary art and its institutions. In this, to borrow the words of the renowned Hong Kong gallery owner Chang Tsang-Zung, the No u-turn exhibition at Beijing's Zhongguo Meishu Guan (February 1989) foreshadowed a "break,"both societal and political, that preceded the upheavals in Chinese urban culture, even in the sphere of so-called "neo-literati" traditional culture, which the major critic Pi Daojian has sought to define and which is also being constantly reinvented.

In Contemporary Chinese Artists the author presents portraits of artists from across the Chinese world, including the diaspora. It complements Making History and adds to the useful monographs - albeit with varying results - published a few years ago by Karen Smith and Martina Köppel-Yang. Wu Hung successively presents painter $\mathrm{Mu}$ Xin, whose tumultuous life in exile (reminiscent of Gao Xingjian's) oscillates between Taiwan and the United States, and installationist Cai Guoqiang, imbued with Daoism, as well as Xu Bing, who initiated what Wu Hung calls "counter-monuments"(p. 25), such as when the artist suspended stencilled calligraphic works from the Great Wall. Such singular works in hallowed places (such as the Ming style see-through costume exhibited in the Summer Palace by Wang Jin in 1997 - a Duchampian act if there was one) go against the norm. Challenging the norm is also what Zhang Dali did after returning from Bologna, when he daubed the walls of Beijing with his strange graffiti featuring by turns a silhouette adorned with a signature. As a new identity marker, the city becomes the laboratory for all possibilities, providing photographer Rong Rong and his contemporaries of East Village with a new territory of ruins or futuristic 
constructions from one end of China to the other, such as the Three Gorges dam, which the director Jia Zhangke filmed along with the painter Liu Xiaodong.

Transfers (memorial, poetic), delocalisation (industrial, human), or decontextualisation (of objects, speech) and defocusing (visual, political) are all phenomena of globalisation. They initiate a process of questioning similar to the domains explored by Arjun Appadurai or Fredric Jameson. Wu Hung relies on them as he does on pragmatism in his art appreciation, not only as a theoretician but also as a curator or artistic advisor. In the tenth chapter, he recounts his moving experience with Song Dong and Zhao Xiangyuan and stresses art's curative properties in the manner of John Dewey, author of Art as Experience. These two works of Wu Hung promote a better understanding of Chinese society and its artists. Wu is to be thanked for his remarkable archival work in reproducing - albeit in black and white - a rich and as yet unpublished iconography. One lacuna is that proper names have not been given in Chinese characters. Notwithstanding this lapse, the book deserves enthusiastic recommendation.

9 Translated by N. Jayaram 